\title{
Galbraith: A Partisan Appraisal
}

\author{
Uma Avaliação Partidária
}

JAMES K. GALBRAITH*

NOTA: Este foi o discurso de John Kenneth Galbraith na sessão de abertura do Colóquio Internacional John Kenneth Galbraith, O Espírito da Inovação, patrocinado pela Université du Littoral. Paris, de 23 a 25 de setembro de 2004. Inicialmente, o Prof. Galbraith leu uma pequena carta de seu pai, onde ele explicou que a idade e a restrição médica impediam sua participação nessa grande homenagem.

PALAVRA-CHAVE: John Kenneth Galbraith.

NOTE: This was John Kenneth Galbraith's keynote speech in the opening session of the International Colloquium John Kenneth Galbraith, The Spirit of Innovation, sponsored by the Université du Littoral. Paris, September 23-25, 2004. Initially Prof. Galbraith read a short letter from his father where he explained that age and medical restraint prevented his attendance at this greater tribute.

KEYWORD: John Kenneth Galbraith

jel classification: B31.

John Kenneth Galbraith always loved the many sessions of exegesis devoted to his work by the Association for Evolutionary Economics, the American Agricultural Economics Association, and even by the American Economics Association on occasional better days. I've attended a fair number of such convocations. I could never bring myself to get quite as much enjoyment out of them as he did. For there is an element of the personal in such tributes that tends to be a little overwhelming. My father is often compared to so fundamental an intellect as Thorstein Veblen, as a brilliant mind, writer and social critic. At one level, who would not be content with that? But I always thought that he deserved more - that indeed Veblen also deserves more than he characteristically gets from such comparison to Galbraith. The deficiency lies in the way they tend to be treated as economists. There is something in the appreciation of the luminous individual that

\footnotetext{
* The author holds the Lloyd M. Bentsen Jr. Chair in Government/Business Relations at the Lyndon B. Johnson School of Public Affairs, The University of Texas at Austin, Austin - TX, United States. E-mail: galbraith@mail.utexas.edu.
} 
speaks, also, to the dark side, that evokes the loner, the evanescent flare, the $c u l d e$ $s a c$ - the man whose message came and perhaps went, while the economists moved on. It never much bothered JKG but it bothers me.

For, like Veblen, Galbraith in my view deserves to be recorded as a transforming figure. Like Veblen, he offers an approach, a manner of thought, a structure - to an economics that manifestly still waits, and greatly needs, to be transformed.

Here I'll sketch a case for that proposition - and then go on to suggest how we may achieve it.

What are the core propositions of Galbraith's thought? The following list is emblematic rather than exclusive. Among other things, I do not deal here with the topics of price control and the economics of strategic bombing on which Galbraith long ago built his technical reputation.

But this list, drawn from his greatest books, captures three themes that are in my view essential.

1. From The Great Crash, we have of course the conviction that financial panics affect real activity. No one in the 19th century or with experience of agriculture ever seriously doubted that the economy runs on credit or that real activity depends on banks. Only in the higher reaches of academic life could such a thing be denied. The denial, nevertheless, took powerful hold. The Great Crash is a wonderful corrective. It has remained continuously in print for fifty years - outselling all of Galbraith's books, or so I believe.

Still more important than the melody are the notes. Here we have not only mass psychology and vulnerable technology - the panic that outruns the ticker, as it did again in the market break of 1987. But The Great Crash also gives us the subtle interplay of players: How National City bribed the son of Peru's president $\$ 450,000$ for the privilege of marketing fifty million dollar loan. As Galbraith notes, "Juan's services were of a rather negative sort. He was paid for not blocking the deal". The debts so accrued forced Peru and other countries similarly traduced to attempt export-led growth. This was blocked by rising tariffs, which precipitated default and helped to set off the panic against the banks.

The Great Crash is built on such stories. Taken together, they teach us that economics, like history, is made at least in part by particular persons. This is a message that the profession has stoutly resisted, preferring always the denatured maximizing abstraction homo economicus to the flesh-and-blood of Ivar Krueger, the Match King.

Krueger deserves to be mentioned today because when he shot himself, on March 12, 1932, he did so in his apartment in Paris. JKG notes that "with the cooperation of the Paris police, the news was withheld until the [New York] market closed... [however] the security system of the Paris police was less than perfect. It is fairly certain that there was heavy selling that morning - including heavy short selling - of Krueger and Toll by continental interests”.

The Great Crash is one of the first great works on the subtle economics of insider operations and financial fraud. But it's not just stories. I can't resist giving you one example of the economic method it contains: 
"To the economist embezzlement is the most interesting of crimes. Alone among the various forms of larceny it has a time parameter. Weeks, months, or years may elapse between the commission of the crime and its discovery. (This is a period, incidentally, when the embezzler has his gain and the man who has been embezzled, oddly enough, feels no loss. There is a net increase in psychic wealth.) At any given time there exists an inventory of undiscovered embezzlement in - or more precisely not in - the country's businesses and banks.

This inventory - perhaps it should be called the bezzle - ... varies in size with the business cycle. In good times people are relaxed, trusting, and money is plentiful.

But even though money is plentiful, there are always many people who need more. Under these circumstances the rate of embezzlement grows, the rate of discovery falls off, and the bezzle increases rapidly. In depression all this is reversed... Audits are penetrating and meticulous. Commercial morality is enormously improved. The bezzle shrinks."

Though the essential precedent for this approach - generalization from example - goes back to Adam Smith, there are not many passages in economics since Smith that illuminate a new subject with such penetration. Can anyone doubt that we could do with more?

2. The Affluent Society is best remembered for its endearing, enduring phrases, above all the "concept of the conventional wisdom", and for its evocative passages on private opulence and public squalor, such as the one about the "family which takes its mauve and cerise, airconditioned, power-steered and power-braked automobile out for a tour [and] passes through cities that are badly paved, made hideous by litter, blighted buildings, and posts for wires that should long since have been put underground..." before going on to "picnic on exquisitely packaged food from a portable icebox by a polluted stream [and spending] the night at a park which is a menace to public health and morals".

But it is much more than that. In The Affluent Society, we find a logical demolition of the orthodox theory of consumer choice. It proceeds from the unassailable observation that stable preferences cannot exist for goods that do not exist. The process of innovation necessarily entails the creation of markets. Thus the Dependence Effect: the dependence of consumption on production and not the other way around. This is, in essence, a plain-English version of the point about instability of preference fields that Philip Mirowski drove home in More Heat than Light three decades later. Enormous trouble could have been saved if the profession had taken the hint the first time.

3. Then we have the theory of economic organization in The New Industrial State. Here Galbraith built on the foundation of Berle and Means, on Joseph Schumpeter and to some extent on Max Weber, on the behavioral formalisms of Herbert A. Simon, and on his own American Capitalism of 1952 and its concept of countervailing power. But the portrait in TNIS is altogether richer, conveying understanding not only of the separation of ownership from control but also the significance of the specific bureaucratic processes that generate corporate decision- 
making and the interplay of company and state. In The New Industrial State, Galbraith challenges us to contemplate rigorously what happens when power passes irrevocably into the organization. He forces us to recognize that the fundamental decision-making process of modern economics - maximization subject to constraint - is untenable in a world of asymmetric information (as Stiglitz has taught us to call it) and negotiated decisions representing the compromised interests of established players. The New Industrial State did not anticipate later developments in many respects. The incursion of the Japanese technostructure (especially in steel and autos) into the American scene in the 1970s, eventually stabilized by market sharing deals under President Reagan, wasn't foreseen in the book. Nor was the return to power of high finance in the 1980s, as the demolition of Bretton Woods restored the role of the banks, and as high interest rates first permitted them to rake in their gains and then, in a repeat of the early 1930s, nearly ruined them all. Galbraith also did not anticipate that part of the technostructure would spin away from the large industrial corporations in the 1990s, becoming a distinct and independently financed economic force, susceptible (as we learned) to bubble and pop.

Nevertheless, The New Industrial State gives us something that nothing else at that time did: a framework for analyzing all of these phenomena in complex organizational terms. This is missing from the class analysis of the Marxists, different from the macro and sectoral analyses of the Keynesians, and alien to the denatured firms and representative households of neoclassical equilibrium. And it is much closer than any of these to the actual decision-making institutions of American capitalism.

One may argue that in the new millennium the large corporation has regained its central position on the American political scene - that we live in what I've called the "Corporate Republic". Indeed one may argue for an understanding of the present American government - the George W. Bush administration - almost precisely in terms of corporate governance as The Industrial State teaches it to be.

- We have the essentially clientelist character of decision making, unable to deliberate in an extended, goal-seeking way, because of the overriding necessity of deference to players who happen to occupy particular roles. Thus we have the capture of strategic direction - in national security, finance, regulation and other areas - by cliques who (like the Technostructure) can lay claim to expertise not available to outsiders, who can manufacture bogus expertise at will, claiming the privilege of dispensing it without fear of substantial contradiction. - We have the public relations apparatus with the unique characteristic of a corporate propaganda machine, namely an inability to tell a truthful story that is consistent from one day to the next. Yet like the press releases of large corporations, this apparatus nevertheless expects and receives deferential treatment from the press. Meanwhile challengers and critics are treated as the financial papers handle unionists and tort lawyers.

- We have the rubber-stamping Board of Directors, which in the modern United States we refer to by the deferential title of "Congress". - We have the shareholders, nominal owners and participants in occasional elections, which the management is determined never under any circumstances to lose. - Above all, we have the Chief Executive Officer as specialist in public relations - the man who spends his time 
on the golf course (or at the ranch) in order to show that he can, in order to advertise to the world that things are under control. Or more precisely to obscure the fact that they are not.

All of these characteristics have analogs in the corporation of The New Industrial State - or would have them, in any modest updating of that analysis. And that, my friends, brings me to my principal message for the morning. If we are weary, as Veblen wrote, of a "moncotyledonous wage doctrine", and a "cryptogamic theory of interest, with involute, loculicidal, tomentous and moniliform variants, what is the cytoplasm, centrosome, or karyokinetic process to which we may turn, and, in which we may find surcease from the metaphysics of normality and controlling principle?"

What are we doing? What are we doing here? Are we merely paying tribute to a great thinker, a brilliant man, a political inspiration? Or are we here for a more serious purpose? Are we part of the project - advanced with force and verve under French student leadership by the Post Autistic Economics movement in recent years - of changing the way economics conducts its affairs? And if our purpose is, as I hope, the latter, then what must we do, together, to bring this about?

The answer will not be found in wit, in literary genius or political celebrity. It can only be found in research. And one thing my father did not do - one thing that he never seriously attempted - was to build a research tradition that would carry on the spirit of his work. Nor, in the struggles of his day between Marxians, Keynesians, and neoclassicals would economics have permitted any such thing. But if the ideas are to survive, that task is before us now.

Needless to say this is a project I've had in view for many years. Let me say a few words about the elements in my work that, I believe, apply the larger Galbraithian spirit to a research program.

First, I and a growing group of students have shown that the study of inequality has operated greatly below potential. The reasons lie in the preference of economists for the analyses of individuals and their characteristics, for the sample survey and the sample statistic.

But inequality is everywhere and always a social characteristic. By its nature the study of inequality relates individuals to each other. The essential task is therefore to discover the predominant patterns of change in the structure of relative pay and incomes. This can be done in fine detail, using data generated by social and political processes. We have done it for the global economy, for Europe, for Russia, China, India, and the United States. The result is what Walt Rostow would call "meso-economics" - an economics of regions, sectors, and industries.

With a rich portrait of the patterns of change, one can move far beyond the brilliant insight of Galbraith's pen, toward numerical propositions that directly confront the conventional wisdom. I'll offer just one example. Is it the case, as so incessantly argued, that European unemployment is due to the excessive equality, the socialist legacy, of European labor markets? The answer, we have shown, is that 
this is not the case ${ }^{1}$. Higher pay inequality in Europe is systematically associated with higher, not lower, unemployment. The details of the finding are for another time and place. The simple message is that the quantitative arts are not the exclusive preserve of adherents to textbook theory.

A second area to which I have been more midwife than parent concerns the problems of corporate governance and what my colleague Bill Black - an economist/lawyer/criminologist with a remarkable history as a whistleblower - calls "control fraud". Control fraud is that type fraud committed by those in control. It constitutes an especially interesting problem for the economics of crime and market failure, for it is a pattern of activity that directly challenges the rubrics of "law and economics" - the concepts for instance of moral hazard, and market discipline. The power of Black's approach is that it calls attention to specific characteristics of control frauds that cannot be accounted for by these ideas. It opens the way to an understanding of corporate behavior which combines the institutional decisionanalysis of The New Industrial State - focusing in this case on the interaction of control frauds and their lawyers and accountants - with the fine personal detail reminiscent of the narrative in The Great Crash.

Third, let me mention the topic on which I cut my teeth as a practitioner: the conduct of monetary policy. I've been working monetary policy for about thirty years now - my longest professional preoccupation. And it is here that my approach is perhaps most directly influenced by my father, even though he cares little for the topic. For while most economists treated monetary policy analysis as substantially a matter of numerical models, I pioneered the application of hermeneutics, of textanalysis, of explication de texte as I learned it in high school in Rennes, to the topic. And I believe that this approach - the deconstruction (if you like) of official statements - has perhaps the greatest promise of transforming the conduct of policy itself. For it turns out that to central bankers, numerical models are mainly matters of rhetoric. They are not serious affairs of scientific conviction. Central bankers care little for evidence, and are insensitive to test statistics however adverse. But they are rather vulnerable to ridicule in public, which can be effected by pointing to elementary illogic in their verbal expression. The spirit of this critical approach is obviously eminently Galbraithian. The shared characteristics in these three areas of my work are community and method.

These are the ingredients that are, frankly, missing in John Kenneth Galbraith's work. They are for lesser men and women to be concerned with, to be sure. But they are also the steps we must take if we wish - as I believe we should wish - to build an enduring intellectual tradition.

Let me close, then, by suggesting ten broad principles for that tradition.

First, the micro/macro distinction should be abolished. It exists in principle to

\footnotetext{
1 James Galbraith and Enrique Garcilazo, "Unemployment, Inequality and the Policy of Europe, 19842000”, Banca Nazionale del Lavoro Quarterly Review, vol. LVII, n 228, March 2004, 3-28.
} 
separate irreconcilable doctrines. The new classicals have recognized this, and have abolished macro.

(As Evelyn Waugh said of Randolph Churchill's surgeons, it was a miracle, they found the only part that was not malignant, and removed it.) We should take the opposite tack: toward a theory of human behavior based on principles of social interaction.

Second, empirical work should be privileged. Real science does not protect bad theory by concentrating on unobservables. It is, rather, a process of interaction between conjecture and evidence. Believe it or not, this could happen in economics too.

Third, our economics should teach the great thinkers, notably Smith, Marx, Keynes, Veblen and Schumpeter - and naturally Galbraith. We need not reinvent the field; nor should we abandon it. The Affluent Society could never have been written without Smith, Ricardo, Marx, Schumpeter, Veblen and Keynes.

Fourth, pop constructs derived from neoclassical abstractions, such as social capital, natural capital and so forth, play a useful but at best a limited role. They are noteworthy as efforts to reconcile neoclassical ideas and policy commitments to real social problems, and their exposition helps in the formation of tactical alliances. But these constructs also extend, rather than attempt to overcome, the logical flaws and empirical difficulties of the neoclassical system.

As such, they lack the essential radicalism of our approach.

Fifth, nor should we accept the reconstruction of economics as an amalgam of interest-group politics, however progressive the groups may themselves be. The fact that race, gender, and the environment are important social issues does not mean that economics requires a separate branch for the economics of race, another for the economics of gender, and another for "sustainable development". It should mean, rather, that the core of our approach should handle these questions (which relate to power, discrimination, entropy, and so forth) in a way that is central to the discipline we espouse.

Sixth, an economics of modern capitalism should study the actual, existing features and behavior of our system. Households, business enterprises of all the types (including some characterized by diminishing and others by increasing returns, some with monopoly power and others without), money and credit systems, governments and their budgets, and the international system are all parts of a nested, hierarchical structure of rule - and convention - setting institutions, of interacting and sometimes conflicting sources of power. That's our subject matter; let's pursue it with full attention to the complexities of its structure.

Seventh, mathematics should clarify the complex implications of simple constructs, not obscure simple ideas behind complex formulae. Dynamical systems, fractal geometries, cellular automata can help us to understand the principles underlying evolutionary social dynamics.

They are also fascinating. They help students learn to think. We do not spurn mathematics - we object only to its use as a bludgeon, to shut off debate.

Eighth, measurement matters. We should embrace the full spectrum of information sources, not merely sample surveys (with their obsessive focus on personal 
characteristics) and the national accounts, but also credit, trade, industrial and financial data. And we should be both creative and aggressive in linking economic measurements to other information: political events, the environment, quality of life, demography, health.

Ninth, a focus on social structures and the data that record them requires new empirical methods. The study of dispersions, of inequalities, is intrinsic to the study of power. The study of power is relational, and cannot be done properly with parametric techniques held hostage to the dogma of hypothesis and test. There is no single formula for empirical learning. Numerical taxonomy, discriminant analysis, multidimensional scaling, and many other techniques are available for studying economic relations. We should use them. There are large gains to be had here, for small investments of effort.

Tenth and finally, our economics is about problems that need to be solved. There remain before us the pursuit of full employment, balanced growth, price stability, development, a sustainable standard of life. That is why students once were attracted to our field. That is why they abandon it now. That is also why, if we develop a coherent research and teaching program that broadly respect the principles outlined above, we will prevail in the long run.

I have no desire to dictate a specific course of action. Pluralism can and indeed must be combined with discipline and rigor. Others these next few days will, I hope, speak to their own innovations. I'm anxious to listen, and to learn. But let's be conscious of two fundamental tests.

One of them is well captured by a remark of Paul Samuelson's, quoted by Richard Parker in his stunning intellectual biography of John Kenneth Galbraith, which will appear next year.

Samuelson writes: "In the history of ideas, the thinker who creates a new synthesis and speaks in telling fashion to a new age is the one who plays the pivotal role in history". Galbraith met that test and so should we.

And then there is a comment by Parker himself, capturing the essence of my father's world view. "The 'truth", he writes, "of an economic theory ultimately lay in its success or failure when applied to policy." Let's not forget our political obligations. As Galbraithians, our task is not only to understand economics and the world that economics attempts to describe. It is also to change it. And to do so in a spirit of abiding liberalism, generosity of spirit, openness and fair play, combined always with humor and a touch of detachment. Those are my father's enduring traits and they should also be ours.

Thank you very much indeed. 